\title{
Biochemical Composition in Edible Tissues of Epinephelus malabaricus (Bloch \& Schneider, 1801) from Nagapattinam Coast, Tamil Nadu, India
}

\author{
Thilakavathi Arunagiri ${ }^{1}$, Arjun Pandian ${ }^{2}$, Samiraj Ramesh $^{3 *}$ \\ ${ }^{1}$ Department of Zoology, PRIST University, Thanjavur - 614 904, Tamil Nadu, India \\ ${ }^{2}$ Department of Biotechnology, PRIST University, Thanjavur - 614 904, Tamil Nadu, India \\ $3^{3 *}$ Department of Microbiology, PRIST University, Thanjavur - 614 904, Tamil Nadu, India \\ "Corresponding Author: marineramesh2020@gmail.com
}

Available online at: www.isroset.org

Received: 21/Jan/2019, Accepted: 11/Feb/2019, Online: 28/Feb/2019

\begin{abstract}
The present study was undertaken to analyze the biochemical composition in relation to season, sex, and size groups in edible tissues of E. malabaricus in Nagapattinam coast, Tamil Nadu, India. Seasonal variations in moisture content ranged between 72.35 and $79.13 \%$, crude protein (68.22 and $73.25 \%$ ), carbohydrate (2.12 and 5.23\%), crude lipid (4.33 and $7.66 \%$ ) and ash content (5.25 and 8.64\%) in all the size groups of both sexes. Among the size groups in both sexes, maximum carbohydrate level was recorded during postmonsoon $(50-60 \mathrm{~cm}$ : female-5.38\%) and minimum during summer $(30-40 \mathrm{~cm}$ : male-2.85\%). Low protein content was noticed in larger size groups and high values in smaller size groups. Most of the size groups in females showed higher protein content than males during all the seasons. The crude protein contents in muscle tissues of the presently studied finfishes showed a relationship with spawning season. High protein levels were observed in muscle during post and pre spawning months and low values during spawning season.
\end{abstract}

Keywords - Biochemical composition, E. malabaricus, protein, carbohydrate, lipid

\section{INTRODUCTION}

Importance of knowing the biochemical composition of edible organisms was emphasized by Stansby [1]. The nutritive values of organisms will remain supportive in the selection and utilization of a particularly advantageous species and also to know which size group and sex will be more adequate and advantageous for consumption from a nutritive point of view. The obvious application of knowledge on the proximate composition of fish has always been needed by dieticians in institutions concerned with mass feeding and by individuals interested in caloric content of foods for weight control $[2,3]$.

The information on proximate composition of fish has fundamental importance in the application of different technological processes $[3,4]$. Whether a fish is considered to be lean or fatty, the actual lipid content has retribution for the technological characteristics post-mortem [8]. Proximate composition is also important as an aspect of quality of unprocessed material, sensory quality and storage constancy [5] and gives an idea of sexual stage [4, 6].

Many of the previous works about the nutritive value of fishes dealt with changes in relation to the age and size of the fishes [7-9]. Studies on biochemical composition of fishes are incomplete without information on seasonal variation. Hence, the present study has been undertaken to analyse the biochemical composition in relation to season, sex, and size groups of edible tissues in E. malabaricus.

\section{MATERIALS AND METHODS}

Collection and preparation of samples: The marine fishes were collected regularly during four seasons (premonsoon, monsoon, postmonsoon and summer) from Nagapattinam coast for a period of one year from July 2016 to June 2017. The collected samples were immediately brought to laboratory in an iced condition. The freshness of fishes was examined by observing the brightness of the eyes, colour of the gills and the texture of the muscles. Then the sexes of fishes were identified and grouped into five size groups based on their total length $(10-20 \mathrm{~cm}, 20-30 \mathrm{~cm}, 30-40 \mathrm{~cm}$, $40-50 \mathrm{~cm} \& 50-60 \mathrm{~cm})$. For the purpose of identification, the publications of Munro [10] and Fischer and Bianchi [11] have been referred.

Biochemical composition: To calculate the moisture content, $1 \mathrm{~g}$ of fresh edible tissue was taken and oven dried at a constant temperature of $105^{\circ} \mathrm{C}$ for 24 hours [12]. Crude protein was estimated by Kjeldahl method [13]. The total carbohydrate in the dried sample was estimated 
spectrophotometrically following the phenol sulphuric acid method [14]. The lipid content in the tissue was estimated by the chloroform: methanol extraction method [15]. Ash content was determined gravimetrically by incinerating $1 \mathrm{~g}$ dried sample in Muffle furnace at about $550^{\circ} \mathrm{C}$ for 6 hours [12] and the results are expressed in percentage dry weight basis. The results of two way analysis of variance (ANOVA) $P<0.05)$ done to test the differences in biochemical composition among the seasons and size groups of males and females.

\section{RESULTS AND DISCUSSION}

Chemical composition of fish varies greatly from one species and one individual to another, depending on age, sex, sea environment and season $[3,7,8]$. In the present study, the variations in biochemical composition in relation to seasons, sexes and size groups are shown in Figs. 1-5. Moisture content ranged between 72.35 and $79.13 \%$. Both the size groups of indeterminates $(10-20$ and $20-30 \mathrm{~cm})$ exhibited low values during premonsoon $(74.15$ and $76.32 \%$, respectively) and monsoon (74.66 and $76.15 \%$, respectively) and high values during summer (77.82 and $79.23 \%$, respectively). Among the size groups in both sexes, high value was recorded during summer (30-40 cm: male-77.81\%) and low value in monsoon $(50-60 \mathrm{~cm}$ : male-73.13\%). Low values were observed in larger size groups and high values in smaller size groups. The moisture content of muscle in all the size groups of males and females was high during spawning months and very low during post spawning months in all the four species studied presently. Similarly, highest percentage of water was observed in muscle during the spawning season of Clarius batrachus [16] and Mugil cephalus [17].

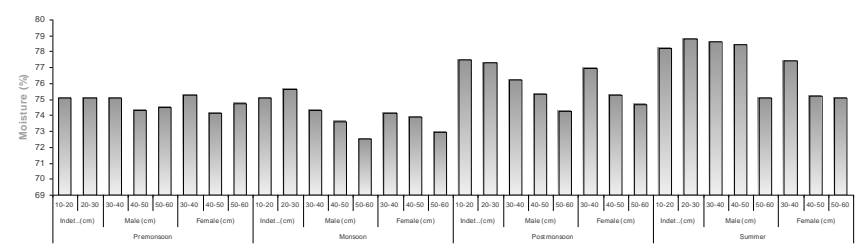

Fig. 1. Variations in moisture content of E. malabaricus

Crude protein values fluctuated between 68.22 and $73.25 \%$. Both the size groups of indeterminates (10-20 and 20-30 cm) showed low values during summer (71.05 and $71.13 \%$, respectively) and high values during postmonsoon (74.12 and $74.11 \%$, respectively). Among the size groups of both sexes, there was a high value recorded during postmonsoon (30-40 cm: female-72.85\%) and low value during summer (50-60 cm: male-68.31\%). Low values were noticed in larger size groups and high values in smaller size groups. Most of the size groups in females showed higher values than males during all the seasons. The crude protein contents in muscle tissues of the presently studied finfishes showed a relationship with spawning season. High protein levels were observed in muscle during post and pre spawning months and low values during spawning season. This corresponds well with the findings of Bano [16], who also observed a fall in the protein content during spawning in Clarius batrachus. Further suggests the accumulation of muscle protein, due to high protein in muscle content during post and pre spawning periods, leads to meet the nitrogen demands of the fish [6, $18]$.

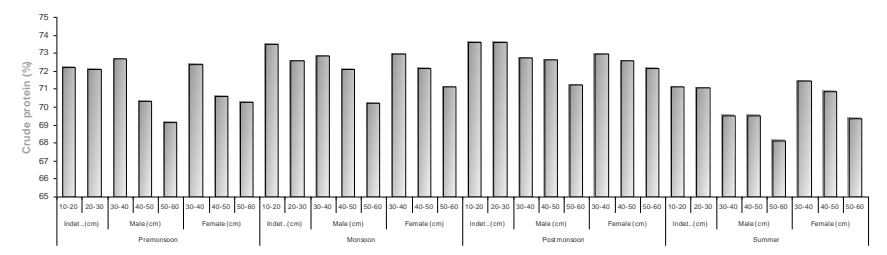

Fig. 2. Variations in crude protein content of E. malabaricus

Carbohydrate values varied between 2.12 and $5.23 \%$. Both the size groups of indeterminates $(10-20$ and $20-30 \mathrm{~cm})$ showed high values during postmonsoon $(2.35$ and $2.55 \%$, respectively) and monsoon (2.22 and $2.35 \%$, respectively) and low during premonsoon (1.66 and $1.95 \%$, respectively) and summer (1.65 and $1.97 \%$, respectively). Among the size groups in both sexes, maximum carbohydrate level was recorded during postmonsoon $(50-60 \mathrm{~cm}$ : female-5.38\%) and minimum during summer $(30-40 \mathrm{~cm}$ : male-2.85\%). Low values were observed in lower size groups and high values in higher size groups. In the species presently studied, smaller size groups showed less carbohydrate compared to larger forms which may perhaps be due to rapid utilization of carbohydrate during growth and accumulation associated with decreasing growth rate. Love [19] concluded from the amount of lactic acid accumulation after death, that larger fishes carry greater reserves of carbohydrate in Gadus morhua.

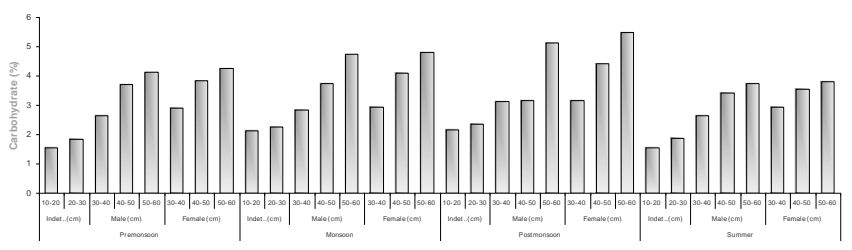

Fig. 3. Variations in carbohydrate content of E. malabaricus

Crude lipid values showed variations from 4.33 to $7.66 \%$. The size groups of indeterminates exhibited the following trend: high values recorded in postmonsoon $(20-30 \mathrm{~cm}$ $5.35 \%)$ and low values noticed during summer $(20-30 \mathrm{~cm}-$ $4.06 \%)$. Among the size groups in both sexes, high value was observed during postmonsoon $(40-50 \mathrm{~cm}$ : female$7.71 \%)$ and low value during summer $(30-40 \mathrm{~cm}$ : male$3.92 \%$ ). Lower size groups exhibited low values and higher size groups showed higher values. 


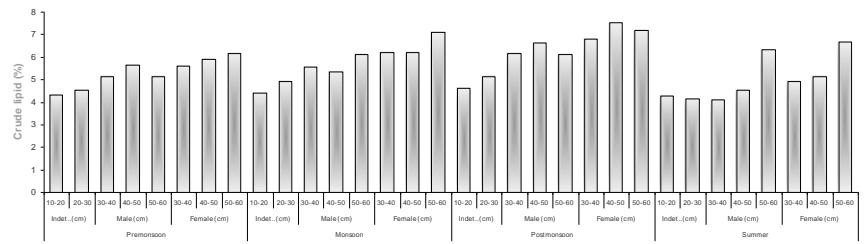

Fig. 4. Variations in crude lipid content of E. malabaricus

Ash content ranged from 5.25 to $8.64 \%$. Both the indeterminates size groups $(10-20$ and $20-30 \mathrm{~cm})$ showed higher (8.19 and $8.24 \%$, respectively) and lower values (8.14 and $8.19 \%$, respectively) of ash in summer and premonsoon season respectively. There was a maximum ash content was observed in E. tauvina (8.14\%) in summer. Similar kind of reports was observed by many researchers in fishes [16, 20, 21]. The maximum ash content observed in present study might be due to the accumulation of inorganic salts in the muscles and seasonal variations in the food availability for fish [22-24].

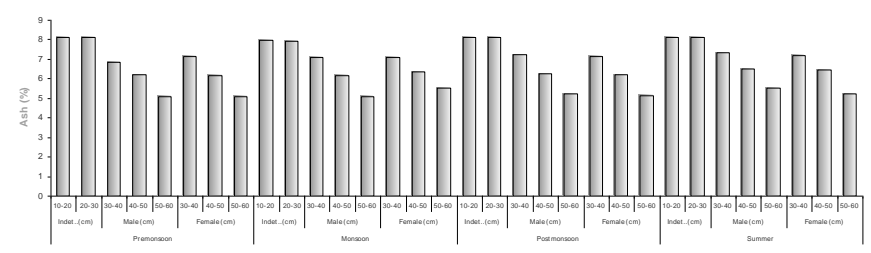

Fig. 5. Variations in ash content of E. malabaricus

\section{CONCLUSION}

The information on proximate composition of fish has fundamental importance in the application of different technological processes. The present study showed that consumption of E. malabaricus during premonsoon and postmonsoon is advantageous in Nagapattinam coast, as good amount of biochemical constituents (crude protein, carbohydrate and crude lipid) were found during these months.

\section{REFERENCES}

[1] M.E. Stansby, Composition of certain species of freshwater fish. I. Introduction. The determination of the variations of composition of fish, Food Research, Vol.19, pp. 231-234, 1954.

[2] M.E. Stansby, Proximate composition of fish. In: Heen, E. and R. Kreuzer (Eds.), Fish in Nutrition. Fishing News (Books) Ltd., London, pp. 55-60, 1962.

[3] M. L. Hamilton, R.P. Haslam, J.A. Napier, O. Sayanova. Metabolic engineering of Phaeodactylum tricornutum for the enhanced accumulation of omega-3 long chain polyunsaturated fatty acids, Metab Eng, Vol. 22, pp.3-9, 2014.

[4] H. H. Huss, El pescado fresco: Su calidad y cambios de calidad. Manual de capacitacion preparado por el programa de capacitacion FAO/DANIDA en Technologia Pesquera y Control de Calidad, Vol. 29, 1988.

[5] Z.E. Sikorski, Technologia de los Products del Mar: Recursos y Composicion Nutritiva, In: Acribia (Ed.), Espana: Primera Edicion 1994.
[6] C. Campoy, V. Escolano-Margarit, T. Anjos, H. Szajewska, R. Uauy, Omega 3 fatty acids on child growth, visual acuity and neurodevelopment, Br J Nutr, Vol.107, pp.85-S106, 2012.

[7] N.M. Bandarra, I. Batista, M.L. Nunes, J.M. Empis, Seasonal variation in the chemical composition of horse-mackerel (Trachurus trachurus). Eur Food Res Technol, pp.525-539, 2001.

[8] D.D. Kitts, M.D. Huynh, C. Hu, A.W. Trites, Seasonal variation in nutrient composition of Alaskan walleye Pollock. Can J Zool, Vol. 82, pp.1408-1415, 2004.

[9] S.K. Raatz, J.T. Silverstein, L. Jahns, M.J. Picklow, Issues of fish consumption for cardiovascular disease risk reduction, Nutrients, Vol. 5, pp. 1081-1097, 2013.

[10] I.S.R. Munro, The marine and freshwater fishes of Ceylon. Dept. of External Affairs, Canberra, Vol. 349, 1955.

[11] W. Fischer, G. Bianchi, FAO species identification sheets for fishery purposes. Western Indian Ocean (Fishing area, 51). Prepared and printed with the support of the Danish International Development Agency (DANIDA). Rome, Food and Agricultural Organization of the United Nations, Vol. I-VI, 1984.

[12] AOAC, Official methods of analysis, $15^{\text {th }}$ edn., Association of Official Analytical Chemists, 1990.

[13] AOAC, Official methods of analysis, $14^{\text {th }}$ edn., Association of Official Analytical Chemists, 1984.

[14] M. Dubois, K.A. Giller, J.K. Hamilton, R.A. Rebors, F. Smith, Colorimetric method for determination of sugars and related substances, Analyt Chem, Vol. 28, pp. 350-356, 1956.

[15] J. Folch, M. Lees, G.H. Sloane Stanly, A simple method for the isolation and purification of total lipids from animal tissues, J Biol Chem, Vol. 26, pp. 497, 1957.

[16] Y, Bano, Seasonal variation in the biochemical composition of Clarius batrachus L., Proc Indian Acad Sci, Vol. 85 B, pp. 147$155,1975$.

[17] H. Das, Seasonal variation in the chemical composition and calorific content of Mugil cephalus (Linnaeus) from Goa waters, Mahasagar, Vol. 11, Issue, 3\&4, pp. 117-134, 1978.

[18] A.K. Jafri, Seasonal changes in the biochemical composition of the fresh water catfish Wallagonia attu, Hydrobiologia, Vol. 33, pp. 497-506, 1969.

[19] Love RM. The chemical biology of fishes. Academic press, London, 1970: Vol. I.

[20] M.B. Perera, S.S. De Silva, Studies on the chemical biology of young grey mullets, Mugil cephalus L, J Fish Biol, Vol.13, pp. 297-304, 1977.

[21] K. Anil, Tyor, Sunil Kumari, Biochemical characterization and antibacterial properties of fish skin mucus of fresh water fish, Hypophthalmichthys Nobilis, Int J Pharm Pharm Sci, Vol. 8, Issue 6, pp. 132-136, 2016.

[22] F.A. Gon Calues-Ferreiro, Composic, a o e valor alimentar de algumas especies de peixe. Boletim de perca, Vol. 33, pp. 89-92, 1951.

[23] Alpana Arya, Evaluation of biochemical and histochemical changes following the combined treatment of mercury and cadmium in a fresh water cat fish, Clarias Batrachus (Linn), Int J Pharm Pharm Sci, Vol. 6, Issue 10, pp. 356-358, 2014.

[24] S. Sumathi, A. Christy Ponni, Seasonal variation in the Carbohydrate content from different tissues of Sepia aculeata in Pazhayar coastal waters, Nagapattinam District, Tamilnadu, International Journal of Scientific Research in Biological Sciences, Vol.5, Issue 5, pp.70-72, 2018. 